\title{
The anti-atherosclerotic effects of tomatoes
}

\section{Hidekatsu Yanai, Hiroki Adachi, Akiko Kawaguchi, Mariko Hakoshima, Yoko Waragai, Tadanao Harigae, Yoshinori Masui, Koki Kakuta, Hidetaka Hamasaki, Hisayuki Katsuyama, Akahito Sako}

Department of Internal Medicine, National Center for Global Health and Medicine Kohnodai Hospital, Chiba, Japan

Corresponding author: Hidekatsu Yanai, MD, PhD, FACP, Department of Internal Medicine, National Center for Global Health and Medicine Kohnodai Hospital, 1-7-1 Kohnodai, Ichikawa, Chiba 272-8516, Japan

Submission date: March $23^{\text {rd }}, 2017$, Acceptance Date: June $27^{\text {th }}$, 2017, Publication Date: June $30^{\text {th }}, 2017$

Citation: Yanai H, Adachi H, Kawaguchi A, Hakoshima M, Waragai Y, Harigae T, Masui Y., The anti-atherosclerotic effects of tomatoes. Functional Foods in Health and Disease 2017; 7(6); 411428

\begin{abstract}
Tomatoes are rich in lycopene, which causes the red coloring of tomatoes. Several reports have suggested lycopene plays a role in the prevention of cardiovascular diseases. In this study, we systematically reviewed the interventional studies using tomatoes or tomato products to understand the anti-atherosclerotic effects of the tomato as a functional food. We found that a significant number of interventional studies reported the anti-atherosclerotic effects of tomatoes, including anti-obesity effects, hypotensive effects, improvement of lipid/glucose metabolism and endothelial function, anti-oxidative and anti-inflammatory effect, and anti-platelet effect; however, the antiplatelet effect was disagreed upon by some studies. Furthermore, we discovered cooking methods significantly affect anti-atherosclerotic effects of tomatoes.
\end{abstract}

Keywords: anti-oxidative effect, atherosclerosis, body weight, tomatoes, serum lipids 


\section{INTRODUCTION}

Tomatoes are rich in lycopene, beta-carotene, folate, potassium, vitamin $\mathrm{C}$ and $\mathrm{E}$, and flavonoids [1]. Lycopene is a non-provitamin. A carotenoid is responsible for the red color of tomatoes [2]. Several reports have suggested lycopene plays a role in the prevention of cardiovascular diseases (CVD), based upon epidemiological studies that demonstrate a dose-response relationship between lycopene and CVD [3]. In the cross-sectional study between tomato-based food product intake and coronary biomarkers in the Women's Health Study with 27, 261 female participants $\geq 45$ years and were free of CVD and cancer, women consuming $\geq 10$ compared with $<1.5$ servings/week of tomato-based food products had significant improvements in total cholesterol (TC) (5.38 vs 5.51 $\mathrm{mmol} / \mathrm{L} ; \mathrm{P}=0.029)$, TC/high-density lipoprotein cholesterol (HDL-C) ratio (4.08 vs $4.22 ; \mathrm{P}=$ 0.046), and hemoglobin A1c (HbA1c) (5.02 vs. 5.13\%; $\mathrm{P}<0.001)$ in multivariable models [4].

In human macrophages, lycopene reduced intracellular TC dose-dependently. This kind of effect was associated with a decrease in cholesterol synthesis through a reduction of activity and expression of 3-hydroxy-3-methylglutaryl coenzyme A reductase, a modulation of low-density lipoprotein (LDL) receptor and acyl-coenzyme A: cholesterol acyltransferase activity [5]. An increase in cholesterol efflux through an enhancement of ATP-binding cassette transporter A1 (ABCA1) and caveolin-1 expression was also observed [5]. Moreover, tomato products have been reported to attenuate the susceptibility of LDL to oxidative modification and inflammatory nuclear factor kappa-light-chain-enhancer of activated B cells (NF-kB) signaling and to the improvement of endothelial function [6,7]. The Caco-2 cells were pretreated with lycopene at different concentrations for $24 \mathrm{~h}$ and then incubated with radioactive micellar cholesterol for $2 \mathrm{~h} \mathrm{[8]}$. Lycopene dose-dependently inhibited cholesterol absorption and reduced expression of NiemannPick C1-like 1 (NPC1L1) protein and NPC1L1 mRNA.

In this study, we systematically reviewed the interventional studies using tomatoes or tomato products, to understand anti-atherosclerotic effects of tomato as a functional food. Furthermore, we will discuss methods of cooking tomatoes to increase efficacy to improve atherosclerosis.

\section{The Interventional Trials Investigating Anti-atherosclerotic Effects of Tomatoes or Tomato Products}

We looked for interventional trials investigating the anti-atherosclerotic effects of tomatoes or tomato products with PubMed until March 2017 (Table 1). We searched for these trials by using the combination of "tomato" with the following words "plasma glucose, cholesterol, LDL-C, HDL-C, triglyceride (TG), blood pressure (BP), body weight, obesity, atherosclerosis, HbA1c, diabetes, insulin resistance, hypertension, CVD, inflammation, cytokine, anti-platelet and antioxidative," and discovered 28 articles. 
Table 1. Clinical studies that investigated anti-atherosclerotic effects of tomato and tomato products in humans

\begin{tabular}{|c|c|c|c|}
\hline Authors & Study design & Subjects & Results/Conclusions \\
\hline \multicolumn{4}{|c|}{ Anti-obesity effet } \\
\hline $\begin{array}{l}\text { Hirose } A \text {, et } \\
\text { al. [9] }\end{array}$ & $\begin{array}{l}\text { An open-label, single-arm study. } \\
\text { The participants refrained from } \\
\text { foods and drinks rich in tomato } \\
\text { and tomato-based products for } \\
2 \text { weeks prior to the study and } \\
\text { during the } 8 \text { weeks of tomato } \\
\text { juice consumption. After the run- } \\
\text { in period, the women were } \\
\text { asked to consume } 200 \text { ml of } \\
\text { unsalted tomato juice, twice } \\
\text { daily for } 8 \text { weeks. } \\
\text { Measurements were performed } \\
\text { at } 4 \text { and } 8 \text { weeks after study } \\
\text { commencement }\end{array}$ & $\begin{array}{l}95 \text { women } \\
\text { (40-60 years) } \\
\text { who had at } \\
\text { least one } \\
\text { menopausal } \\
\text { symptom }\end{array}$ & $\begin{array}{l}\text { Resting energy expenditures increased }(1980 \pm 368 \\
\mathrm{kcal} / \mathrm{day}, 2108 \pm 440 \mathrm{kcal} / \mathrm{day}, 2149 \pm 470 \mathrm{kcal} / \mathrm{day} ; \mathrm{P} \\
=0.0030) \text {, serum TG decreased in the subgroup of } \\
\text { women }(\mathrm{n}=22) \text { who had high TG }(150 \mathrm{mg} / \mathrm{dL} \text { or } \\
\text { higher) at baseline }(237.8 \pm 88.9 \mathrm{mg} / \mathrm{dl}, 166.7 \pm 86.1 \\
\mathrm{mg} / \mathrm{dl}, 170.9 \pm 109.7 \mathrm{mg} / \mathrm{dl} ; \mathrm{P}=0.0002) .\end{array}$ \\
\hline $\begin{array}{l}\text { Li YF, et al. } \\
{[10]}\end{array}$ & $\begin{array}{l}\text { The subjects continued with } \\
\text { their normal diet and exercise } \\
\text { schedule, but were given } 280 \mathrm{ml} \\
\text { of tomato juice (containing } 32.5 \\
\text { mg of lycopene) daily for } 2 \\
\text { months }\end{array}$ & $\begin{array}{l}30 \text { young } \\
\text { females }(20- \\
\text { to } 30 \text { years) } \\
\text { with } \mathrm{BMI} \geq \\
20 \mathrm{~kg} / \mathrm{m}^{2}\end{array}$ & $\begin{array}{l}\text { Tomato juice supplementation significantly reduced } \\
\text { body weight, body fat, waist circumference, BMI, } \\
\text { and serum TC, monocyte chemoattractant protein- } \\
1 \text {, and thiobarbituric reactive substances, while } \\
\text { significantly increasing serum adiponectin, TG, and } \\
\text { lycopene. These effects are unrelated to body fat } \\
\text { changes. }\end{array}$ \\
\hline $\begin{array}{l}\text { Vinha AF, et } \\
\text { al. [11] }\end{array}$ & $\begin{array}{l}\text { During } 4 \text { weeks, daily, } \\
\text { participants ingested a raw ripe } \\
\text { tomato }(\sim 90 \mathrm{~g}) \text { before lunch. } \\
\text { Their anthropometric and } \\
\text { biochemical parameters were } \\
\text { measured repeatedly during the } \\
\text { follow-up time }\end{array}$ & $\begin{array}{l}35 \text { young } \\
\text { women (age, } \\
19.6 \pm 1.3 \\
\text { years) }\end{array}$ & $\begin{array}{l}\text { Significant reductions were observed on body } \\
\text { weight }(-1.09 \pm 0.12 \mathrm{~kg}), \% \text { fat }(-1.54 \pm 0.52 \%) \text {, } \\
\text { fasting blood glucose }(-5.29 \pm 0.80 \mathrm{mg} / \mathrm{dl}) \text {, TG }(-8.31 \\
\pm 1.34 \mathrm{mg} / \mathrm{dl}), \mathrm{TC}(-10.17 \pm 1.21 \mathrm{mg} / \mathrm{dl}) \text {, and uric } \\
\text { acid }(-0.16 \pm 0.04 \mathrm{mg} / \mathrm{dl}) \text {. }\end{array}$ \\
\hline
\end{tabular}

Anti-hypertensive effect

Study participants received 200 g raw tomato daily for 8 weeks.

Shidfar $\mathrm{F}$, Serum glucose, apoB and apoAet al. [12] I and homocysteine were measured at the beginning and end of 8 weeks.

\begin{tabular}{|l|l}
\hline & \\
2 double blind cross-over \\
treatment periods of 6 weeks \\
each, with standardized tomato \\
Paran E, et
\end{tabular}

al. [13] Plasma concentrations of lycopene, nitrite and nitrate were measured and correlated with BP changes was studied
32 type 2 diabetic patients

54 subjects with moderate hypertension treated with one or two antihypertensi ve drugs
There were significant decrease in systolic and diastolic BP and also a significant increase in apoA-I at the end of study compared with initial values $(P=$ $0.0001, P=0.0001$ and $P=0.013$, respectively). $200 \mathrm{~g}$ raw tomato per day had a favored effect on BP and apoA-I so it might be beneficial for reducing cardiovascular risk associated with type 2 diabetes.

There was a significant reduction of systolic BP after 6 weeks of tomato extract supplementation, from $145.8 \pm 8.7$ to $132.2 \pm 8.6 \mathrm{mmHg}(\mathrm{P}<0.001)$ and $140.4 \pm 13.3$ to $128.7 \pm 10.4 \mathrm{mmHg}(P<0.001)$ in the two groups. There was a decline in diastolic BP from $82.1 \pm 7.2$ to $77.9 \pm 6.8 \mathrm{mmHg}(P=0.001)$ and from $80.1 \pm 7.9$ to $74.2 \pm 8.5 \mathrm{mmHg}(P=0.001)$. There was no significant change in systolic and diastolic BP during the placebo period. Serum lycopene level increased from $0.11 \pm 0.09$ to $0.30 \pm$ $01.3 \mu \mathrm{mol} / \mathrm{l}$ after tomato extract therapy $(P<0.001)$. There was a significant correlation between systolic BP and lycopene levels $(r=-0.49, P<0.001)$. 


\begin{tabular}{|c|c|c|c|}
\hline $\begin{array}{l}\text { Engelhard } \\
\text { YN, et al. } \\
{[14]}\end{array}$ & $\begin{array}{l}\text { A single-blind, placebo- } \\
\text { controlled trial. Subjects entered } \\
\text { a 4-week placebo period, then } \\
\text { an 8-week treatment period with } \\
\text { tomato extract, and a 4-week } \\
\text { control period with placebo }\end{array}$ & $\begin{array}{l}31 \text { subject } \\
\text { with grade-1 } \\
\text { hypertension } \\
\text { who required } \\
\text { no } \\
\text { antihypertensi } \\
\text { ve or lipid- } \\
\text { lowering drug } \\
\text { therapy }\end{array}$ & $\begin{array}{l}\text { Systolic BP decreased from } 144 \pm 1.1 \text { (mean } \pm S E) \text { to } \\
134 \pm 2 \mathrm{mmHg}(\mathrm{P}<.001) \text {, and diastolic } \mathrm{BP} \\
\text { decreased from } 87.4 \pm 1.2 \text { to } 83.4 \pm 1.2 \mathrm{mmHg}(\mathrm{P}< \\
.05) . \text { No changes in } \mathrm{BP} \text { were demonstrated during } \\
\text { placebo periods. Thiobarbituric acid-reactive } \\
\text { substances, a lipid peroxidation products } \mathrm{marker} \text {, } \\
\text { decreased from } 4.58 \pm 0.27 \text { to } 3.81 \pm 0.32 \mathrm{nmol} / \mathrm{mg}(\mathrm{P} \\
<0.05) \text {. No significant changes were found in lipid } \\
\text { parameters. }\end{array}$ \\
\hline \multicolumn{4}{|c|}{ Improvement of lipid and glucose matabolism } \\
\hline $\begin{array}{l}\text { Bohn T, et } \\
\text { al. [15] }\end{array}$ & $\begin{array}{l}\text { A single arm intervention study. } \\
\text { Healthy men and women } \\
\text { consumed a soy germ-fortified } \\
\text { juice daily ( } 300 \mathrm{ml} \text { supplying } 66 \\
\text { mg isoflavones and } 22 \mathrm{mg} \\
\text { lycopene) for } 8 \text { weeks }\end{array}$ & $\begin{array}{l}18 \text { healthy } \\
\text { men and } \\
\text { women }\end{array}$ & $\begin{array}{l}\text { Juice consumption significantly improved resistance } \\
\text { of LDL+VLDL-C to copper-mediated oxidation }(P= \\
0.039), \mathrm{HDL}-\mathrm{C}(47.3 \pm 15.8 \text { to } 51.7 \pm 14.8 \mathrm{mg} / \mathrm{dl}, \mathrm{P}< \\
0.001) \text {, and TC:HDL-C ratio }(4.25 \pm 1.59 \text { to } 3.63 \pm \\
1.16, \mathrm{P}<0.001) \text { at } 8 \text { weeks. }\end{array}$ \\
\hline $\begin{array}{l}\text { Silaste ML, } \\
\text { et al. [16] }\end{array}$ & $\begin{array}{l}\text { The diet intervention included a } \\
\text { baseline period, a } 3 \text {-week low } \\
\text { tomato diet (no tomato products } \\
\text { allowed) and a } 3 \text {-week high } \\
\text { tomato diet ( } 400 \mathrm{ml} \text { tomato juice } \\
\text { and } 30 \mathrm{mg} \text { tomato ketchup } \\
\text { daily) }\end{array}$ & $\begin{array}{l}21 \text { healthy } \\
\text { study subjects }\end{array}$ & $\begin{array}{l}\text { TC was reduced by } 5.9 \%(P=0.002) \text { and } L D L-C \text { by } \\
12.9 \%(P=0.0002) \text { with the high tomato diet } \\
\text { compared to the low tomato diet. The changes in } \\
\text { TC and LDL-C correlated significantly with the } \\
\text { changes in serum lycopene, beta-carotene and } \\
\text { gamma-carotene concentrations. The level of LDL } \\
\text { to resist formation of oxidized phospholipids } \\
\text { increased } 13 \%(P=0.02) \text { in response to the high } \\
\text { tomato diet. }\end{array}$ \\
\hline $\begin{array}{l}\text { Madrid AE, } \\
\text { et al. [17] }\end{array}$ & $\begin{array}{l}\text { Study participants received a } \\
\text { supplement of pure tomato juice } \\
\text { during } 7 \text { days. At baseline, at } \\
\text { the end of the supplementarion } \\
\text { period and eight days after the } \\
\text { end of the supplementation, a } \\
\text { blood sample was drawn }\end{array}$ & $\begin{array}{l}17 \text { healthy } \\
\text { volunteers }\end{array}$ & $\begin{array}{l}\text { Lycopene level increased early and significantly in } \\
\text { comparison with basal levels }(48 \% ; \mathrm{P}<0.05) \text {. Total } \\
\text { antioxidant capacity, catalase and superoxide } \\
\text { dismutase did not change significantly. HDL-C } \\
\text { increased significantly in } 5.6 \pm 4.3 \mathrm{mg} / \mathrm{dl}(\mathrm{P}<0.002) \\
\text { on the second sampling period, improving TC/HDL- } \\
\text { C. It returned to baseline in the third period. }\end{array}$ \\
\hline $\begin{array}{l}\text { Agarwal S, } \\
\text { et al. [18] }\end{array}$ & $\begin{array}{l}\text { Dietary lycopene was provided } \\
\text { using tomato juice, spaghetti } \\
\text { sauce, and tomato oleoresin for } \\
\text { a period of } 1 \text { week each. Blood } \\
\text { samples were collected at the } \\
\text { end of each treatment }\end{array}$ & $\begin{array}{l}19 \text { healthy } \\
\text { human } \\
\text { subjects }\end{array}$ & $\begin{array}{l}\text { Dietary supplementation of lycopene significantly } \\
\text { increased serum lycopene levels by at least twofold. } \\
\text { Although there was no change in serum TC, LDL-C, } \\
\text { or HDL-C, serum lipid peroxidation and LDL } \\
\text { oxidation were significantly decreased. }\end{array}$ \\
\hline $\begin{array}{l}\text { Collins JK, } \\
\text { et al. [19] }\end{array}$ & $\begin{array}{l}\text { Study participants consumed a } \\
\text { low lycopene diet with no added } \\
\text { lycopene (control) or } \\
\text { supplemented with watermelon } \\
\text { or tomato juice each containing } \\
20 \text { mg lycopene. Subjects } \\
\text { consumed each treatment for } 3 \\
\text { weeks in a crossover design }\end{array}$ & $\begin{array}{l}10 \text { healthy } \\
\text { men and } \\
\text { women }\end{array}$ & $\begin{array}{l}\text { Compared to the control diet, the lycopene- } \\
\text { containing foods did not affect plasma lipid } \\
\text { concentrations or antioxidant biomarkers. }\end{array}$ \\
\hline
\end{tabular}




\begin{tabular}{|c|c|c|c|}
\hline $\begin{array}{l}\text { Cuevas- } \\
\text { Ramos D, } \\
\text { et al. [20] }\end{array}$ & $\begin{array}{l}\text { A randomized, single-blinded, } \\
\text { controlled clinical trial. Study } \\
\text { participants completed a } 2 \text {-week } \\
\text { run-in period on an isocaloric } \\
\text { diet and then were randomized } \\
\text { to receive } 300 \mathrm{~g} \text { of cucumber } \\
\text { (control group) or two uncooked } \\
\text { Roma tomatoes a day for } 4 \\
\text { weeks }\end{array}$ & $\begin{array}{l}50 \text { individuals } \\
\text { (women }=41 ; \\
82 \%) \text { with age } \\
(42 \pm 15.5 \\
\text { years) and } \\
\text { BMI }(27.6 \pm 5.0 \\
\left.\mathrm{kg} / \mathrm{m}^{2}\right)\end{array}$ & $\begin{array}{l}\text { A significant increase in HDL-C was observed in the } \\
\text { tomato group (from } 36.5 \pm 7.5 \mathrm{mg} / \mathrm{dl} \text { to } 41.6 \pm 6.9 \\
\mathrm{mg} / \mathrm{dl}, \mathrm{P}<0.0001 \mathrm{vs} \text {. the control group). After } \\
\text { stratification by gender, the difference in HDL-C } \\
\text { levels was only significant in women. The mean } \\
\text { HDL-C increase was } 5.0 \pm 2.8 \mathrm{mg} / \mathrm{dl} \text {. A linear } \\
\text { regression model that adjusted for parameters that } \\
\text { impact HDL-C levels showed an independent } \\
\text { association between tomato consumption and the } \\
\text { increase in HDL-C }\left(\mathrm{r}^{2}=0.69 ; \mathrm{P}<0.0001\right) \text {. }\end{array}$ \\
\hline $\begin{array}{l}\text { Burton- } \\
\text { Freeman B, } \\
\text { et al. [21] }\end{array}$ & $\begin{array}{l}\text { Study participants consumed } \\
\text { high-fat meals to induce } \\
\text { postprandial oxidative stress on } \\
\text { two separate occasions } \\
\text { containing either processed } \\
\text { tomato product or non-tomato } \\
\text { alternative. Blood samples were } \\
\text { collected at } 0,30,60,90,120 \\
\text { min, then hourly until } 360 \text { min }\end{array}$ & $\begin{array}{l}12 \text { women } \\
\text { and } 13 \text { men } \\
\text { (age, } 27 \pm 8 \\
\text { years; BMI, } \\
22 \pm 2 \mathrm{~kg} / \mathrm{m}^{2} \text { ) }\end{array}$ & $\begin{array}{l}\text { Both meals induced increases in plasma glucose, } \\
\text { insulin, and lipid concentrations }(P<0.05) \text {. A trend } \\
\text { for higher TG at }>240 \text { min was observed after the } \\
\text { tomato meal }(P=0.006) \text {. Tomato significantly } \\
\text { attenuated high-fat meal-induced LDL oxidation }(P< \\
0.05) \text { and rise in interleukin- } 6(p<0.0001) \text {. }\end{array}$ \\
\hline $\begin{array}{l}\text { Lazarus } \\
\text { SA, et al. } \\
{[22]}\end{array}$ & $\begin{array}{l}\text { A double-blind, parallel-group } \\
\text { clinical trial in which participants } \\
\text { were assigned to consume } 250 \\
\mathrm{ml} \text { of clarified tomato juice ( } \mathrm{n}= \\
10 ; 7 \text { men and } 3 \text { women) or } \\
\text { placebo tomato-flavored } \\
\text { beverage ( } \mathrm{n}=10 ; 7 \text { men and } 3 \\
\text { women) daily for } 3 \text { weeks }\end{array}$ & $\begin{array}{l}\text { Patients with } \\
\text { type } 2 \\
\text { diabetes ( } \mathrm{n}= \\
18 \text { ) or } \\
\text { impaired } \\
\text { glucose } \\
\text { tolerance ( } \mathrm{n}= \\
\text { 2). } 14 \text { men } \\
\text { and } 6 \text { women } \\
\text { aged } 43 \text { to } 82 \\
\text { years with } \\
\mathrm{BMI}(\mathrm{mean} \pm \\
\mathrm{SD}, 30.5 \pm 4.9 \\
\mathrm{~kg} / \mathrm{m}^{2} \text { ) }\end{array}$ & $\begin{array}{l}\text { No significant differences were observed in } \mathrm{HbA} 1 \mathrm{c} \\
\text { following supplementation with tomato juice }(7.1 \pm \\
1.2 \% \text { vs } 6.9 \pm 1.0 \% ; \mathrm{P}=0.55) \text { or placebo beverage } \\
(6.7 \pm 1.0 \% \text { vs } 6.6 \pm 1.0 \% ; \mathrm{P}=0.68) \text {. Platelet } \\
\text { aggregation decreased following supplementation } \\
\text { with tomato juice as compared with the placebo } \\
\text { group. }\end{array}$ \\
\hline \multicolumn{4}{|c|}{ Anti-oxidative effect } \\
\hline $\begin{array}{l}\text { Bub A, et } \\
\text { al. [23] }\end{array}$ & $\begin{array}{l}\text { Randomly assigned to control } \\
\text { (mineral water) or intervention } \\
\text { group (tomato juice). Subjects of } \\
\text { the tomato juice group } \\
\text { consumed daily } 330 \mathrm{ml} \text { tomato } \\
\text { juice for } 8 \text { weeks }\end{array}$ & $\begin{array}{l}50 \text { elderly } \\
\text { subjects }\end{array}$ & $\begin{array}{l}\text { Tomato juice consumption reduced LDL-oxidation } \\
\text { and improved antioxidant status in R-allele carriers } \\
\text { (paraoxonase1-192 polymorphism), but not in the } \\
\text { QQ genotype group. }\end{array}$ \\
\hline $\begin{array}{l}\text { Upritchard } \\
\text { JE, et al. } \\
\text { [24] }\end{array}$ & $\begin{array}{l}\text { Randomized to receive tomato } \\
\text { juice ( } 500 \mathrm{ml} / \text { day), vitamin } \mathrm{E} \\
\text { ( } 800 \mathrm{U} / \text { day), vitamin } \mathrm{C}(500 \\
\text { mg/day), or placebo treatment } \\
\text { for } 4 \text { weeks }\end{array}$ & $\begin{array}{l}57 \text { patients } \\
\text { with well- } \\
\text { controlled } \\
\text { type } 2 \\
\text { diabetes aged } \\
<75 \text { years }\end{array}$ & $\begin{array}{l}\text { Plasma lycopene levels increased nearly } 3 \text {-fold }(P= \\
0.001) \text {, and the lag time in isolated LDL oxidation by } \\
\text { copper ions increased by } 42 \%(P=0.001) \text { in } \\
\text { patients during supplementation with tomato juice, } \\
\text { which was almost as effectively as supplementation } \\
\text { with a high dose of vitamin } E \text {. }\end{array}$ \\
\hline
\end{tabular}




\begin{tabular}{|c|c|c|c|}
\hline $\begin{array}{l}\text { García- } \\
\text { Alonso FJ, } \\
\text { et al. [25] }\end{array}$ & $\begin{array}{l}\text { A 2-week intervention trial } \\
\text { involving the daily intake of } 500 \\
\mathrm{ml} \text { of } \mathrm{n}-3 \text { PUFA-enriched juice ( } \mathrm{n} \\
=11 \text { ) or plain tomato juice ( } \mathrm{n}= \\
\text { 7). Each serving of enriched } \\
\text { juice provided } 250 \mathrm{mg} \text { of EPA } \\
\text { plus DHA. Both juices provided } \\
\text { natural antioxidant compounds } \\
\text { such as phenolics }(181 \mathrm{mg}) \text { and } \\
\text { lycopene }(26.5 \mathrm{mg})\end{array}$ & $\begin{array}{l}18 \text { healthy } \\
\text { women }\end{array}$ & $\begin{array}{l}\text { Intervention with the enriched juice had no effect on } \\
\text { sereum lipid profile. The serum antioxidant status } \\
\text { improved following juice intake, as revealed by an } \\
\text { increase in total antioxidant capacity and a slight } \\
\text { decrease in lipid peroxidation. Serum homocysteine } \\
\text { decreased following n-3 PUFA-enriched juice } \\
\text { consumption. A decrease in vascular adhesion } \\
\text { molecule } 1 \text { was also noted after intake of either } \\
\text { plain or enriched tomato juice, whereas intercellular } \\
\text { adhesion molecule } 1 \text { only decreased following intake } \\
\text { of the enriched juice. }\end{array}$ \\
\hline $\begin{array}{l}\text { Pourahmadi } \\
\text { Z, et al. } \\
{[26]}\end{array}$ & $\begin{array}{l}\text { Randomly allocated to the } \\
\text { intervention group consuming } \\
330 \mathrm{ml} / \text { day of tomato juice }(\mathrm{n}= \\
40) \text { or control consuming water } \\
(\mathrm{n}=35) \text {, for a } 20 \text {-day period. }\end{array}$ & $\begin{array}{l}75 \text { overweight } \\
\text { or obese } \\
\text { female } \\
\text { students }\end{array}$ & $\begin{array}{l}\text { Lycopene consumption had no effect on total } \\
\text { antioxidant capacity and antioxidant enzyme activity } \\
\text { (superoxide dismutase, glutathione peroxidase, and } \\
\text { catalase). }\end{array}$ \\
\hline $\begin{array}{l}\text { Ghavipour } \\
\text { M, et al. } \\
{[27]}\end{array}$ & $\begin{array}{l}\text { Randomly received tomato juice } \\
(\mathrm{n}=32,330 \mathrm{ml} / \text { day) or water ( } \mathrm{n} \\
=28) \text { for } 20 \text { days }\end{array}$ & $\begin{array}{l}64 \text { overweight } \\
\text { or obese (BMI } \\
\left.\geqq 25 \mathrm{~kg} / \mathrm{m}^{2}\right) \\
\text { female } \\
\text { students }\end{array}$ & $\begin{array}{l}\text { Plasma total antioxidant capacity and erythrocyte } \\
\text { antioxidant enzymes increased and serum } \\
\text { malondialdehyde decreased in the intervention } \\
\text { group compared with baseline and with the control } \\
\text { group ( } P<0.05) \text {. In the intervention group, similar } \\
\text { results were found in overweight, but not in obese, } \\
\text { subjects. }\end{array}$ \\
\hline $\begin{array}{l}\text { Lee CY, et } \\
\text { al. [28] }\end{array}$ & $\begin{array}{l}\text { Placebo (rice and olive oil) or } \\
\text { tomato (tomato sauce, rice and } \\
\text { olive oil) meals were provided to } \\
\text { the volunteers. Blood and urine } \\
\text { samples were taken before } \\
\text { consumption of meal }(0 \mathrm{~h} \text { ) and } \\
2,4,6,24 \text { and } 48 \mathrm{~h} \text { after meal }\end{array}$ & $\begin{array}{l}10 \text { Healthy } \\
\text { male subjects }\end{array}$ & $\begin{array}{l}\text { Consumption of tomato sauce increased plasma } \\
\text { lycopene level by } 5-22 \% \text {, with a maximum level at } \\
24 \mathrm{~h}(\mathrm{P}<0.01) \text { after the meal. Plasma } \mathrm{F}(2)- \\
\text { isoprostanes, hydroxyeicosatetraenoic acid } \\
\text { products, allantoin and urinary } 8 \text {-hydroxy-2'- } \\
\text { deoxyguanosine did not change after either meal, } \\
\text { but urinary } \mathrm{F}(2) \text {-isoprostanes }(\mathrm{P}<0.05) \text { significantly } \\
\text { decreased at } 48 \mathrm{~h} \text { compared to } 0 \mathrm{~h} \text { after the tomato } \\
\text { sauce meal. }\end{array}$ \\
\hline $\begin{array}{l}\text { Deplanque } \\
\text { X, et al. } \\
{[29]}\end{array}$ & $\begin{array}{l}\text { In a randomized, double-blind, } \\
\text { parallel-groups, placebo- } \\
\text { controlled study, study } \\
\text { participants were randomly } \\
\text { assigned to a daily dose of } \\
\text { carotenoid-rich tomato extract } \\
\text { or placebo during } 2 \text { weeks. } \\
\text { Oxidized LDL, glucose, insulin, } \\
\text { and TG were measured for } 8 \mathrm{~h} \\
\text { after ingestion of a high-fat meal } \\
\text { before and at the end of } \\
\text { intervention }\end{array}$ & $\begin{array}{l}\text { 146 healthy } \\
\text { normal weight } \\
\text { individuals }\end{array}$ & $\begin{array}{l}\text { Plasma lycopene, phytofluene, and phytoene were } \\
\text { increased throughout the study period in the } \\
\text { carotenoid-rich tomato extract group compared to } \\
\text { placebo. Carotenoid-rich tomato extract ingestion } \\
\text { significantly improved changes in oxidized LDL } \\
\text { response to high-fat meal compared to placebo } \\
\text { after } 2 \text { weeks }(P<0.0001) \text {. Changes observed in } \\
\text { glucose, insulin, and TG were not statistically } \\
\text { significant after } 2 \text { weeks of supplementation. }\end{array}$ \\
\hline $\begin{array}{l}\text { Bub A, et al. } \\
{[30]}\end{array}$ & $\begin{array}{l}\text { In this randomized cross-over } \\
\text { study, study participants on a } \\
\text { low-carotenoid diet received } 330 \\
\text { ml/day tomato juice ( } 37.0 \mathrm{mg} \\
\text { lycopene, } 1.6 \mathrm{mg} \text { beta-carotene) } \\
\text { or carrot juice ( } 27.1 \mathrm{mg} \text { beta- } \\
\text { carotene, } 13.1 \mathrm{mg} \text { alpha- } \\
\text { carotene) for } 2 \text { weeks }\end{array}$ & $\begin{array}{l}22 \text { healthy, } \\
\text { non-smoking } \\
\text { men }\end{array}$ & $\begin{array}{l}\text { Tomato juice consumption had no significant effects } \\
\text { on paraoxonase } 1 \text { activity. However, tomato juice } \\
\text { consumption reduced }(P<0.05) \text { plasma } \\
\text { malondialdehyde in } Q R / R R \text { (paraoxonase } 1-192 \\
\text { genotypes) as compared to } Q Q \text { subjects. }\end{array}$ \\
\hline
\end{tabular}


Anti-platelet effect

A 7-h time-course study was carried out in subjects to

O'Kennedy determine the ex vivo efficacy of 23 cannulated $\mathrm{N}$, et al. a supplement drink containing [31] tomato extract and the onset and duration of antiplatelet effects human

subjects

supplementation with a dose of tomato extract equivalent to 6 tomatoes was observed. The observed effects persisted for $>12 \mathrm{~h}$. Coagulation variables were not affected.
A significant inhibition of baseline platelet function, from $2.9 \pm 1.4 \%$ (optimal ADP concentrations; $P=$ 0.03 ) to $20.0 \pm 4.9 \%$ (suboptimal ADP

concentrations; $\mathrm{P}<0.001$ ), $3 \mathrm{~h}$ after

Significant reductions in ex vivo platelet aggregation induced by ADP and collagen were observed $3 \mathrm{~h}$

A randomized, double-blinded, 90 healthy after supplementation with doses of tomato extract placebo-controlled crossover human

O'Kennedy study. Changes from baseline subjects

$\mathrm{N}$, et al. hemostatic function were selected for

[32] measured $3 \mathrm{~h}$ after consumption normal of tomato extract-enriched or platelet control supplements function equivalent to 6 and 2 tomatoes. No significant effects were observed for control supplements. A dose response to tomato extract was found at low levels of platelet stimulation. Inhibition of platelet function was greatest in a subgroup with the highest plasma homocysteine $(P<0.05)$ and $C$-reactive protein concentrations $(P<0.001)$.

Anti-inflammatory effect

Thies $F$, et al. [33] capsules group (10 mg/day) for 12 weeks. Blood samples were collected at baseline, at 6 weeks, and after the intervention

$$
\text { supp }
$$$$
\text { interver }
$$

After a 4-week run-in period with a low-tomato diet, study participants were randomly ssigned into a control diet group (low in tomato-based foods), a high-tomato-based diet volunteers (94
group, or a control diet $\quad$ men and 131 women) aged 40-65 years

Randomly allocated to an Ghavipour intervention group $(n=53)$ or a $M$, et al. control group $(n=53)$ consuming [34] $330 \mathrm{ml} /$ day of tomato juice or water, respectively, for 20 days

\section{6} overweight or obese female students
None of Inflammatory markers, markers of insulin resistance and sensitivity, and lipid concentrations and arterial stiffness changed significantly after the dietary intervention. These data indicate that a relatively high daily consumption of tomato-based products (equivalent to $32-50 \mathrm{mg}$ lycopene/day) or lycopene supplements (10 mg/day) is ineffective at reducing conventional CVD risk markers in moderately overweight, healthy, middle-aged individuals.

Serum interleukin- 8 and tumor necrosis factor- $\alpha$ decreased significantly in the intervention group compared with the control group and with baseline. This effect was confined to subjects with overweight. Among obese subjects, serum interleukin- 6 was decreased in the intervention group compared with the control group, with no differences in interleukin-8 and tumor necrosis factor- $\alpha$ observed. 
Effect on endothelial function

\begin{tabular}{|c|c|c|c|}
\hline $\begin{array}{l}\text { Xaplanteris } \\
\mathrm{P} \text {, et al. } \\
{[35]}\end{array}$ & $\begin{array}{l}\text { A randomized, single-blind, } \\
\text { crossover design. The study } \\
\text { consisted of a supplementation } \\
\text { arm ( } 70 \mathrm{~g} \text { tomato paste } \\
\text { containing } 33.3 \mathrm{mg} \text { of lycopene) } \\
\text { and a control arm, during which } \\
\text { no tomato paste was added to } \\
\text { their regular diet }\end{array}$ & $\begin{array}{l}19 \text { volunteers } \\
\text { (age, } 39 \pm 13 \\
\text { years; } 8 \\
\text { men/11 } \\
\text { women) }\end{array}$ & $\begin{array}{l}\text { Tomato supplementation led to an overall flow- } \\
\text { mediated dilatation increase compared with the } \\
\text { control period }(P=0.047) \text {. At day } 1 \text {, flow-mediated } \\
\text { dilatation was not significantly increased }(P= \\
0.329) \text {. By day } 15 \text {, tomato supplementation resulted } \\
\text { in an increase in flow-mediated dilatation by } 3.3 \pm \\
1.4 \% \text {, whereas at the control arm, flow-mediated } \\
\text { dilatation declined by }-0.5 \pm 0.6 \%(P=0.03) \text {. Total } \\
\text { oxidative status decreased at the end of the } \\
\text { supplementation period compared with baseline } \\
\text { values }(P=0.038) \text {. }\end{array}$ \\
\hline $\begin{array}{l}\text { Stangl V, et } \\
\text { al. [36] }\end{array}$ & $\begin{array}{l}\text { Randomised study participants } \\
\text { to consume a buttered roll with } \\
\text { and without tomato purée ( } 70 \mathrm{~g} \text { ) } \\
\text { in a cross-over design. } \\
\text { Endothelial-dependent flow- } \\
\text { mediated dilation and } \\
\text { endothelial-independent nitro- } \\
\text { mediated dilation of the brachial } \\
\text { artery were assessed. Acute ( } 24 \\
\text { h) and long-term ( } 7 \text { days) } \\
\text { effects were examined after } \\
\text { daily consumption of the tested } \\
\text { meal }\end{array}$ & $\begin{array}{l} \\
\\
19 \text { healthy } \\
\text { non-smoking } \\
\text { postmenopau } \\
\text { sal women }\end{array}$ & $\begin{array}{l}\text { Plasma lycopene levels increased from } 0.30 \text { to } 0.42 \\
\text { and to } 0.74 \mu \mathrm{m} \text { after } 24 \mathrm{~h} \text { and } 7 \text { days, respectively, } \\
\text { with tomato purée consumption. These data } \\
\text { indicated an effective absorption of the tomato } \\
\text { product. However, both acute and long-term tomato } \\
\text { purée consumption had no effects on endothelium- } \\
\text { dependent or -independent dilation of the brachial } \\
\text { artery. }\end{array}$ \\
\hline
\end{tabular}

BMI, body mass index; BP, blood pressure; CVD, cardiovascular disease; DHA, docosahexaenoic acid; EPA, eicosapentaenoic acid; HDL-C, high-density lipoprotein-cholesterol; HbA1c, hemoglobin A1c; LDL, low-density lipoprotein; PUFA, polyunsaturated fatty acids; TC, total cholesterol; TG, triglyceride; VLDL-C, very low-density lipoprotein-cholesterol

\section{Anti-obesity effect}

In an open-label, single-arm study, the women were asked to consume $200 \mathrm{ml}$ of unsalted tomato juice, twice daily for 8 weeks. Resting energy expenditures significantly increased from $1980 \pm 368$ $\mathrm{kcal} /$ day to $2108 \pm 440 \mathrm{kcal} /$ day after 4 weeks and $2149 \pm 470 \mathrm{kcal} /$ day after 8 weeks, which could contribute to anti-obesity effect [9]. Two-month tomato juice supplementation significantly reduced body weight, body fat, waist circumference, and BMI in young females with BMI over 20 $\mathrm{kg} / \mathrm{m}^{2}$ [10]. During 4 weeks, young women ingested a raw ripe tomato ( $90 \mathrm{~g} /$ day) before lunch. Significant reductions were observed on body weight $(-1.09 \pm 0.12 \mathrm{~kg})$ and $\%$ fat $(-1.54 \pm 0.52 \%)$ [11]. 


\section{Anti-hypertensive effect}

Thirty-two type 2 diabetic patients received $200 \mathrm{~g}$ raw tomato daily for 8 weeks. There was a significant reduction in systolic and diastolic BP at the end of study compared with the baseline [12]. In 2 double blind cross-over treatment periods of 6 weeks with standardized tomato extract or placebo, 54 subjects with moderate hypertension treated with one or two antihypertensive drugs were enrolled. There was a significant reduction in systolic BP after 6 weeks of tomato extract supplementation, from $145.8 \pm 8.7$ to $132.2 \pm 8.6 \mathrm{mmHg}$ and $140.4 \pm 13.3$ to $128.7 \pm 10.4 \mathrm{mmHg}$ in the two groups [13]. There was a decline in diastolic BP from 82.1 \pm 7.2 to $77.9 \pm 6.8 \mathrm{mmHg}$ and from $80.1 \pm 7.9$ to $74.2 \pm 8.5 \mathrm{mmHg}$. There was no significant change in systolic and diastolic BP during the placebo period. There was a significant correlation between systolic BP and lycopene levels. In a single-blind, placebo-controlled trial, 31 subject with grade-1 hypertension who required no anti-hypertensive or lipid-lowering drug therapy entered a 4-week placebo period, then an 8-week treatment period with tomato extract, and a 4-week control period with placebo [14]. Systolic BP significantly decreased from $144 \pm 1.1$ (mean \pm SE) to $134 \pm 2 \mathrm{mmHg}$, and diastolic BP decreased from $87.4 \pm 1.2$ to $83.4 \pm 1.2 \mathrm{mmHg}$. No changes in BP were demonstrated during placebo periods.

\section{Improvement of lipid and glucose metabolism}

Ingestion of tomato and tomato-based products decreased serum TG in women with high TG [9]. Two-month tomato juice supplementation significantly reduced serum TC, while significantly increasing serum TG, in addition to reduction of body weight, body fat, waist circumference, and BMI. These effects are unrelated to changes in body fat [10]. Four-week ingestion of a raw ripe tomato before lunch lead to reduction in fasting blood glucose $(-5.29 \pm 0.80 \mathrm{mg} / \mathrm{dl})$, TG ($8.31 \pm 1.34 \mathrm{mg} / \mathrm{dl})$, and TC $(-10.17 \pm 1.21 \mathrm{mg} / \mathrm{dl})$ [11]. Daily $200 \mathrm{~g}$ raw tomato for 8 weeks induced a significant increase in apoA-I, which is the main apolipoprotein of HDL ( $\mathrm{P}=0.013)$ [12].

Reduction of TC $[10,11,16]$, LDL-C [16], TC/HDL-C [15, 17], TG [9], and plasma glucose [11] by ingestion of tomato have been reported. However, increase in TG by tomato ingestion was reported in two trials $[10,21]$. Elevation of $\operatorname{HDL}-\mathrm{C}[15,17,20]$ by tomato ingestion were observed in three trials. A significant influence of tomato ingestion on serum lipids were denied by three trials $[14,18,19]$.

In a double-blind, parallel-group clinical trial, patients with type 2 diabetes or impaired glucose tolerance were assigned to consume $250 \mathrm{ml}$ of tomato juice or placebo tomato-flavored beverage daily for 3 weeks [22]. No significant differences were observed in HbA1c following 
supplementation with tomato juice $(7.1 \pm 1.2 \%$ vs $6.9 \pm 1.0 \% ; \mathrm{P}=0.55)$ or placebo beverage $(6.7 \pm 1.0 \%$ vs $6.6 \pm 1.0 \% ; \mathrm{P}=0.68)$.

\section{Anti-oxidative effect}

A lipid peroxidation products maker was significantly decreased by an 8-week treatment with tomato extract [14]. A soy germ-fortified juice (22 $\mathrm{mg}$ lycopene) consumption for 8 weeks improved resistance of LDL and very low-density lipoprotein (VLDL) to copper-mediated oxidation [15]. A 3-week high tomato diet increased the LDL level to resist formation of oxidized phospholipids [16]. A single administration of processed tomato product significantly attenuated high-fat meal-induced LDL oxidation [21]. Other seven trials suggested that tomato or tomato product ingestion increased antioxidant capacity and the resistance of LDL to oxidation [23-25, 27-30, 36].

However, in the study by Madrid AE, a 7-day supplement of pure tomato juice did not change total anti-oxidant capacity, catalase and superoxide dismutase [17]. A 3-week consumption of tomato juice containing $20 \mathrm{mg}$ lycopene and $330 \mathrm{ml} /$ day of tomato juice for 20 days also did not affect anti-oxidant biomarkers $[19,26]$.

\section{Anti-platelet effect}

Platelet aggregation decreased following supplementation with tomato juice for 3 weeks as compared with the placebo group [22]. A 7-h time-course study was carried out in subjects to determine the ex vivo efficacy of a supplement drink containing tomato extract and the onset and duration of anti-platelet effects [31]. A significant inhibition of baseline platelet function $3 \mathrm{~h}$ after supplementation with a dose of tomato extract equivalent to 6 tomatoes was observed. The observed effects persisted for $>12 \mathrm{~h}$. Coagulation variables were not affected. In a randomized, double-blinded, placebo-controlled crossover study, significant reductions in ex vivo platelet aggregation induced by ADP and collagen were observed $3 \mathrm{~h}$ after supplementation with doses of tomato extract equivalent to 6 and 2 tomatoes [32]. No significant effects were observed for control supplements. A dose response to tomato extract was found at low levels of platelet stimulation.

\section{Anti-inflammatory effect}

Reduction of monocyte chemoattractant protein-1 [10], vascular adhesion molecule 1 [25], interleukin-6, interleukin-8, and tumor necrosis factor- $\alpha$ [34] by ingestion of tomato juice were observed. However, in another study, a tomato-based diet failed to reduce inflammatory markers 


\section{Effect on endothelial function}

A randomized, single-blind, crossover study consisted of a supplementation arm ( $70 \mathrm{~g}$ tomato paste containing $33.3 \mathrm{mg}$ of lycopene) and a control arm [35]. Tomato supplementation led to an increase in flow-mediated dilatation compared with the control period. At day 1, flow-mediated dilatation was not significantly increased. By day 15, tomato supplementation resulted in an increase in flowmediated dilatation, while at the control arm flow-mediated dilatation declined. In a randomized cross-over study, participants were asked to consume a buttered roll with and without tomato purée (70 g) [36]. Plasma lycopene levels increased after $24 \mathrm{~h}$ and 7 days, respectively, with tomato purée consumption. However, both acute and long-term tomato purée consumption had no effects on endothelium-dependent or -independent dilation of the brachial artery.

\section{The limitation of present study}

We have to mention the limitation of our study. We searched the interventional trials investigating anti-atherosclerotic effects of tomato or tomato products using only Pubmed. Admittedly, we should have used not less than three search engines.

\section{Influences of cooking methods of tomatoes on anti-atherosclerotic effects}

An assessment of the consumption of tomato products, plasma lycopene concentration, and their interrelationship in a nationally representative sample of elderly British people was performed [37]. Consumption of tomatoes made a significant contribution to plasma lycopene concentration. Age, plasma cholesterol concentration, and smoking habit determined plasma lycopene concentration. Ganji V, et al. investigate the relation between serum lycopene concentrations and sex, age, geographical location, race-ethnicity, education, alcohol, smoking, BMI, BP, serum TC and TG, and intakes of fat, tomatoes and tomato-based products in 3,413 individuals aged 17-90 years by using data from the Third National Health and Nutrition Examination Survey, 1988-1994 [38]. Sex, age, geographical region, socioeconomic status, serum TC, smoking, and intakes of fat, tomatoes,

pizza, and pasta were significant determinants of serum lycopene concentrations in the United States.

How should we cook tomatoes to improve anti-atherosclerotic effects? Tangerine tomatoes (Solanum lycopersicum) are rich in tetra-cis-lycopene, a result from natural variation in carotenoid isomerase. A marked 8.5-fold increase in lycopene bioavailability with tangerine tomato juice 
compared to red tomato juice was observed [39]. In a split plot design, 17 men and women consumed tomatoes which had received minimal additional heating and 16 others consumed extensively additionally heated tomatoes $\left(1 \mathrm{~h}\right.$ at $\left.100^{\circ} \mathrm{C}\right)$ [40]. These tomatoes were not mildly or severely homogenized. Homogenization significantly increased plasma lycopene [40]. Additional heating tended to increase plasma lycopene [40]. Similar effects to those for lycopene were discovered for beta-carotene.

In a comparative study the availability of a low oral lycopene dosage of $5 \mathrm{mg} /$ day from different food matrices was assessed [41]. Twenty-two female adults were randomized in three groups and were advised to minimize their carotenoid intake for two weeks. After supplementation with tomato juice, the plasma lycopene increased significantly, while remaining unchanged during intake of tomatoes, thereby suggesting that lycopene from tomato juice (processed tomatoes) was better absorbed from the intestine than lycopene from raw tomatoes [41]. Thirty-six healthy subjects consumed a lycopene-free diet for 2 weeks and were then assigned to one of three $(\mathrm{n}=$ 12) intervention groups consuming daily, single servings of sauce (21 mg lycopene per (1/2) cup), soup (12 mg lycopene per $1 \mathrm{cup}$ ), or juice (17 mg lycopene per $8 \mathrm{oz}$ ) for 4 weeks [42]. Following intervention, plasma lycopene concentrations increased significantly for the sauce, soup, and juice compared with baseline by 192\% $(\mathrm{P}<0.0001), 122 \%(\mathrm{P}<0.0001)$ and $92 \%(\mathrm{P}<0.0001)$, respectively. Ingestion of tomato paste was found to yield 2.5-fold higher total lycopene peak concentration $(\mathrm{P}<0.005)$ and 3.8-fold higher area under the curve responses $(\mathrm{P}<0.001)$ than ingestion of fresh tomatoes, indicating that the bioavailability of lycopene is greater from tomato paste than from fresh tomatoes in humans [43]. Stahl W, et al. studied the uptake of lycopene from processed (boiled with $1 \%$ corn oil for $1 \mathrm{~h}$ ) and unprocessed tomato juice in humans [44]. Lycopene concentrations in human serum increased only when processed tomato juice was consumed. To evaluate the effect of adding oil to tomato juice (not treated with heat) on the bioavailability of plasma carotenoids and postprandial lipid response, a randomized, controlled, crossover feeding trial was performed [45]. Eleven healthy volunteers were assigned to receive a single ingestion of $750 \mathrm{~g}$ of tomato juice containing $10 \%$ of refined olive oil and $750 \mathrm{~g}$ of tomato juice without oil on two different days. All lycopene isomers increased significantly in subjects consuming tomato juice with oil, and LDL-C and TC decreased significantly $6 \mathrm{~h}$ after the consumption of tomato juice with oil, which correlated significantly with an increase of translycopene and 5-cis-lycopene, respectively. To test the postprandial effects of a single dose of raw tomatoes, tomato sauce, and tomato sauce with refined olive oil on cardiovascular disease risk factors, Valderas-Martinez P, et al. performed an open, prospective, randomized, cross-over, 
controlled feeding trial in 40 healthy subjects who randomly received: raw tomatoes, tomato sauce, tomato sauce with refined olive oil and sugar water on a single occasion on four different days [46]. A single tomato intake in any form decreased plasma TC, TG, and plasma inflammatory biomarkers, and increased plasma HDL-C compared to the control intervention. The changes of plasma interleukin- 6 and vascular cell adhesion molecule-1, and lymphocyte function-associated antigen-1 from T-lymphocytes and CD36 from monocytes were significantly greater after tomato sauce with refined olive oil than after raw tomatoes and tomato sauce interventions, concluding that tomato intake has beneficial effects on cardiovascular risk factors, especially cooked and enriched with oil. Burton-Freeman B, et al. examined clinical trials comparing the efficacy of lycopene supplements with tomato products on CVD risk factors including oxidative stress, inflammation, endothelial function, BP, and lipid metabolism [47]. With the exception of BP management where lycopene supplementation was favored, tomato intake provided more favorable results on cardiovascular risk endpoints than lycopene supplementation did.

\section{CONCLUSION}

A significant number of interventional studies reported the anti-atherosclerotic effects of tomatoes, including anti-obesity effect, hypotensive effect, improvement of lipid/glucose metabolism and endothelial function, and anti-oxidative and anti-inflammatory effects, in addition to anti-platelet effect. We also discovered cooking methods significantly affect anti-atherosclerotic effects of tomatoes. However, since a tomato-based diet did not show efficacy in some studies, we should make a clear cut difference between tomatoes and tomato-based diet. Thus, we should perform more studies that focus on the active components of tomatoes.

Abbreviations: ATP-binding cassette transporter A1 (ABCA1); body mass index (BMI); blood pressure (BP); cardiovascular disease (CVD); docosahexaenoic acid (DHA); eicosapentaenoic acid (EPA); high-density lipoprotein-cholesterol (HDL-C); hemoglobin A1c (HbAlc); lowdensity lipoprotein (LDL); Niemann-Pick C1-like 1 (NPC1L1); nuclear factor kappa-light-chainenhancer of activated B cells (NF-kB); polyunsaturated fatty acids (PUFA); total cholesterol (TC); triglyceride (TG); very low-density lipoprotein-cholesterol (VLDL-C)

Competing Interests: The authors have no financial interests or conflicts of interest.

Authors' contribution: All authors contributed to this study. 


\section{REFERENCES}

1. Willcox JK, Catignani GL, Lazarus S. Tomatoes and cardiovascular health. Crit Rev Food Sci Nutr. 2003; 43:1-18.

2. Story EN, Kopec RE, Schwartz SJ, Harris GK. An update on the health effects of tomato lycopene. Annu Rev Food Sci Technol. 2010; 1:189-210.

3. Mordente A, Guantario B, Meucci E, Silvestrini A, Lombardi E, Martorana GE, Giardina B, Böhm V. Lycopene and cardiovascular diseases: an update. Curr Med Chem. 2011; 18:1146-63.

4. Sesso HD, Wang L, Ridker PM, Buring JE. Tomato-based food products are related to clinically modest improvements in selected coronary biomarkers in women. J Nutr. 2012; 142:326-33.

5. Palozza P, Catalano A, Simone RE, Mele MC, Cittadini A. Effect of lycopene and tomato products on cholesterol metabolism. Ann Nutr Metab. 2012; 61:126-34.

6. Maruyama C, Imamura K, Oshima S, Suzukawa M, Egami S, Tonomoto M, Baba N, Harada M, Ayaori M, Inakuma T, Ishikawa T. Effects of tomato juice consumption on plasma and lipoprotein carotenoid concentrations and the susceptibility of low density lipoprotein to oxidative modification. J Nutr Sci Vitaminol (Tokyo). 2001; 47:213-21.

7. Armoza A, Haim Y, Bashiri A, Wolak T, Paran E. Tomato extract and the carotenoids lycopene and lutein improve endothelial function and attenuate inflammatory NF- $\mathrm{kB}$ signaling in endothelial cells. J Hypertens. 2013; 31:521-9

8. Zou J, Feng D. Lycopene reduces cholesterol absorption through the downregulation of Niemann-Pick C1-like 1 in Caco-2 cells. Mol Nutr Food Res. 2015; 59:2225-30.

9. Hirose A, Terauchi M, Tamura M, Akiyoshi M, Owa Y, Kato K, Kubota T. Tomato juice intake increases resting energy expenditure and improves hypertriglyceridemia in middle-aged women: an open-label, single-arm study. Nutr J. 2015; 14:34.

10. Li YF, Chang YY, Huang HC, Wu YC, Yang MD, Chao PM. Tomato juice supplementation in young women reduces inflammatory adipokine levels independently of body fat reduction. Nutrition. 2015; 31:691-6.

11. Vinha AF, Barreira SV, Costa AS, Alves RC, Oliveira MB. Pre-meal tomato (Lycopersicon esculentum) intake can have anti-obesity effects in young women? Int $\mathrm{J}$ Food Sci Nutr. 2014; 65:1019-26.

12. Shidfar F, Froghifar N, Vafa M, Rajab A, Hosseini S, Shidfar S, Gohari M. The effects of tomato consumption on serum glucose, apolipoprotein B, apolipoprotein A-I, 
homocysteine and blood pressure in type 2 diabetic patients. Int J Food Sci Nutr. 2011; 62:289-94.

13. Paran E, Novack V, Engelhard YN, Hazan-Halevy I. The effects of natural antioxidants from tomato extract in treated but uncontrolled hypertensive patients. Cardiovasc Drugs Ther. 2009; 23:145-51.

14. Engelhard YN, Gazer B, Paran E. Natural antioxidants from tomato extract reduce blood pressure in patients with grade-1 hypertension: a double-blind, placebo-controlled pilot study. Am Heart J. 2006; 151:100.

15. Bohn T, Blackwood M, Francis D, Tian Q, Schwartz SJ, Clinton SK. Bioavailability of phytochemical constituents from a novel soy fortified lycopene rich tomato juice developed for targeted cancer prevention trials. Nutr Cancer. 2013; 65:919-29.

16. Silaste ML, Alfthan G, Aro A, Kesäniemi YA, Hörkkö S. Tomato juice decreases LDL cholesterol levels and increases LDL resistance to oxidation. Br J Nutr. 2007; 98:1251-8.

17. Madrid AE, Vásquez ZD, Leyton AF, Mandiola C, Escobar FJA. Short-term Lycopersicum esculentum consumption may increase plasma high density lipoproteins and decrease oxidative stress. Rev Med Chil. 2006; 134:855-62.

18. Agarwal S, Rao AV. Tomato lycopene and low density lipoprotein oxidation: a human dietary intervention study. Lipids. 1998; 33:981-4.

19. Collins JK, Arjmandi BH, Claypool PL, Perkins-Veazie P, Baker RA, Clevidence BA. Lycopene from two food sources does not affect antioxidant or cholesterol status of middle-aged adults. Nutr J. 2004;3:15.

20. Cuevas-Ramos D, Almeda-Valdés P, Chávez-Manzanera E, Meza-Arana CE, BritoCórdova G, Mehta R, Pérez-Méndez O, Gómez-Pérez FJ. Effect of tomato consumption on high-density lipoprotein cholesterol level: a randomized, single-blinded, controlled clinical trial. Diabetes Metab Syndr Obes. 2013; 6:263-73.

21. Burton-Freeman B, Talbot J, Park E, Krishnankutty S, Edirisinghe I. Protective activity of processed tomato products on postprandial oxidation and inflammation: a clinical trial in healthy weight men and women. Mol Nutr Food Res. 2012; 56:622-31.

22. Lazarus SA, Bowen K, Garg ML. Tomato juice and platelet aggregation in type 2 diabetes. JAMA. 2004; 292:805-6.

23. Bub A, Barth S, Watzl B, Briviba K, Herbert BM, Lührmann PM, Neuhäuser-Berthold M, Rechkemmer G. Paraoxonase 1 Q192R (PON1-192) polymorphism is associated with reduced lipid peroxidation in R-allele-carrier but not in QQ homozygous elderly subjects 
on a tomato-rich diet. Eur J Nutr. 2002; 41:237-43.

24. Upritchard JE, Sutherland WH, Mann JI. Effect of supplementation with tomato juice, vitamin $\mathrm{E}$, and vitamin $\mathrm{C}$ on LDL oxidation and products of inflammatory activity in type 2 diabetes. Diabetes Care. 2000; 23:733-8.

25. García-Alonso FJ, Jorge-Vidal V, Ros G, Periago MJ. Effect of consumption of tomato juice enriched with n-3 polyunsaturated fatty acids on the lipid profile, antioxidant biomarker status, and cardiovascular disease risk in healthy women. Eur J Nutr. 2012; 51:415-24.

26. Pourahmadi Z, Mahboob S, Saedisomeolia A, Reykandeh MT. The Effect of Tomato Juice Consumption on Antioxidant Status in Overweight and Obese Females. Women Health. 2015; 55:795-804.

27. Ghavipour M, Saedisomeolia A, Djalali M, Sotoudeh G, Eshraghyan MR, Moghadam AM, Wood LG. Tomato juice consumption reduces systemic inflammation in overweight and obese females. Br J Nutr. 2013; 109:2031-5.

28. Lee CY, Isaac HB, Huang SH, Long LH, Wang H, Gruber J, Ong CN, Kelly RP, Halliwell B. Limited antioxidant effect after consumption of a single dose of tomato sauce by young males, despite a rise in plasma lycopene. Free Radic Res. 2009; 43:622-8.

29. Deplanque X, Muscente-Paque D, Chappuis E. Proprietary tomato extract improves metabolic response to high-fat meal in healthy normal weight subjects. Food Nutr Res. $2016 ; 60: 32537$.

30. Bub A, Barth SW, Watzl B, Briviba K, Rechkemmer G. Paraoxonase 1 Q192R (PON1192) polymorphism is associated with reduced lipid peroxidation in healthy young men on a low-carotenoid diet supplemented with tomato juice. Br J Nutr. 2005; 93:291-7.

31. O'Kennedy N, Crosbie L, van Lieshout M, Broom JI, Webb DJ, Duttaroy AK. Effects of antiplatelet components of tomato extract on platelet function in vitro and ex vivo: a timecourse cannulation study in healthy humans. Am J Clin Nutr. 2006; 84:570-9.

32. O'Kennedy N, Crosbie L, Whelan S, Luther V, Horgan G, Broom JI, Webb DJ, Duttaroy AK. Effects of tomato extract on platelet function: a double-blinded crossover study in healthy humans. Am J Clin Nutr. 2006; 84:561-9.

33. Thies F, Masson LF, Rudd A, Vaughan N, Tsang C, Brittenden J, Simpson WG, Duthie S, Horgan GW, Duthie G. Effect of a tomato-rich diet on markers of cardiovascular disease risk in moderately overweight, disease-free, middle-aged adults: a randomized controlled trial. Am J Clin Nutr. 2012; 95:1013-22. 
34. Ghavipour M, Sotoudeh G, Ghorbani M. Tomato juice consumption improves blood antioxidative biomarkers in overweight and obese females. Clin Nutr. 2015; 34:805-9.

35. Xaplanteris P, Vlachopoulos C, Pietri P, Terentes-Printzios D, Kardara D, Alexopoulos N, Aznaouridis K, Miliou A, Stefanadis C. Tomato paste supplementation improves endothelial dynamics and reduces plasma total oxidative status in healthy subjects. Nutr Res. 2012; 32:390-4.

36. Stangl V, Kuhn C, Hentschel S, Jochmann N, Jacob C, Böhm V, Fröhlich K, Müller L, Gericke C, Lorenz M. Lack of effects of tomato products on endothelial function in human subjects: results of a randomised, placebo-controlled cross-over study. Br J Nutr. 2011; 105:263-7.

37. Re R, Mishra GD, Thane CW, Bates CJ. Tomato consumption and plasma lycopene concentration in people aged $65 \mathrm{y}$ and over in a British national survey. Eur J Clin Nutr. $2003 ; 57: 1545-54$.

38. Ganji V, Kafai MR; Third National Health and Nutrition Examination Survey, 1998-1994. Population determinants of serum lycopene concentrations in the United States: data from the Third National Health and Nutrition Examination Survey, 1988-1994. J Nutr. 2005; 135:567-72.

39. Cooperstone JL, Ralston RA, Riedl KM, Haufe TC, Schweiggert RM, King SA, Timmers CD, Francis DM, Lesinski GB, Clinton SK, Schwartz SJ. Enhanced bioavailability of lycopene when consumed as cis-isomers from tangerine compared to red tomato juice, a randomized, cross-over clinical trial. Mol Nutr Food Res. 2015; 59:658-69.

40. van het Hof KH1, de Boer BC, Tijburg LB, Lucius BR, Zijp I, West CE, Hautvast JG, Weststrate JA. Carotenoid bioavailability in humans from tomatoes processed in different ways determined from the carotenoid response in the triglyceride-rich lipoprotein fraction of plasma after a single consumption and in plasma after four days of consumption. J Nutr. 2000; 130:1189-96.

41. Böhm V, Bitsch R. Intestinal absorption of lycopene from different matrices and interactions to other carotenoids, the lipid status, and the antioxidant capacity of human plasma. Eur J Nutr. 1999; 38:118-25.

42. Allen CM1, Schwartz SJ, Craft NE, Giovannucci EL, De Groff VL, Clinton SK. Changes in plasma and oral mucosal lycopene isomer concentrations in healthy adults consuming standard servings of processed tomato products. Nutr Cancer. 2003; 47:48-56.

43. Gärtner C, Stahl W, Sies H. Lycopene is more bioavailable from tomato paste than from 
fresh tomatoes. Am J Clin Nutr. 1997; 66:116-22.

44. Stahl W, Sies H. Uptake of lycopene and its geometrical isomers is greater from heatprocessed than from unprocessed tomato juice in humans. J Nutr. 1992; 122:2161-6.

45. Arranz S, Martínez-Huélamo M, Vallverdu-Queralt A, Valderas-Martinez P, Illán M, Sacanella E, Escribano E, Estruch R, Lamuela-Raventos RM. Influence of olive oil on carotenoid absorption from tomato juice and effects on postprandial lipemia. Food Chem. 2015; 168:203-10.

46. Valderas-Martinez P, Chiva-Blanch G, Casas R, Arranz S, Martínez-Huélamo M, UrpiSarda M, Torrado X, Corella D, Lamuela-Raventós RM, Estruch R. Tomato Sauce Enriched with Olive Oil Exerts Greater Effects on Cardiovascular Disease Risk Factors than Raw Tomato and Tomato Sauce: A Randomized Trial. Nutrients. 2016; 8:170.

47. Burton-Freeman B, Sesso HD. Whole food versus supplement: comparing the clinical evidence of tomato intake and lycopene supplementation on cardiovascular risk factors. Adv Nutr. 2014; 5:457-85. 